\title{
Homenagem a Luiz de Sousa Junior
}

ROMUALDO PORTELA DE OLIVEIRA

Presidente da ANPAE

Nesta ocasião, vimos a público lamentar a perda do Prof. Luiz de Sousa Junior, da Universidade Federal da Paraíba (UFPB), e Anpaeano de longa data, falecido neste início de ano, vítima da pandemia do COVID 19. Não é tarefa fácil escrever uma dedicatória a uma pessoa querida que nos deixou há tão pouco tempo e, principalmente, sabendo que tal perda poderia ser evitada. Sua ausência pode ser debitada à incúria e irresponsabilidade do atual governo federal e sua política genocida.

Luiz ocupava o posto de Coordenador Adjunto dos Programas Profissionais da Área de Educação da Capes. Sua partida prematura consterna a todos nós. Deixa uma substantiva produção na área de Financiamento da Educação e relevante contribuição à administração pública, tendo sido Secretário de Educação de João Pessoa, Membro do Conselho Estadual de Educação do Estado da Paraíba, Secretário Geral da UFPB, entre outros postos na Administração Pública.

Profundamente comprometido com a educação pública, particularmente com a educação básica, seu objeto de estudo unia de maneira ímpar a leveza no trato e a firmeza na defesa de suas convicções.

Graduado em Economia pela UFPB (1988), na pós-graduação abraçou a área de educação, tendo realizado seu mestrado na mesma universidade (1994) e, posteriormente, seu doutorado, na Faculdade de Educação da USP (2003). Sua tese, intitulada "Financiamento da educação: os impactos do Fundef na educação básica do Estado da Paraíba", produzida no bojo da pesquisa nacional sobre avaliação dos impactos do Fundef então em realização por meio de uma rede de pesquisadores de 12 estados, marca o florescimento entre nós desse campo de estudo.

Seu trabalho analisa com muita perspicácia as modificações decorrentes da redivisão de recursos promovida pelo Fundef. É um dos primeiros trabalhos acadêmicos que se debruça, em detalhes, a estudar os impactos do fundo, chamando a atenção para duas consequências importantes. De um lado, evidencia o aprofundamento do processo de transferência de matrículas das redes estaduais para as municipais, que ficou conhecida como municipalização do ensino fundamental. Mesmo em situações em que a responsabilidade municipal 
para com o ensino fundamental já era grande, como no Nordeste, o poder indutor dos recursos extras aportados para os municípios funcionaram como um poderoso estímulo, mudando significativamente a distribuição da oferta do ensino fundamental na educação brasileira. De outro, o impacto redistributivo que essas políticas geraram, contribuindo tanto para a melhoria do salário dos professores, aviltantes em muitas redes municipais do Norte e do Nordeste, e para reduzir a desigualdade do gasto por aluno entre as diferentes redes de ensino. Tais impactos são as principais razões da legitimidade que as políticas de fundos contábeis adquiriram com o passar dos anos.

Sua partida prematura deixa uma lacuna em nossos corações e na área de conhecimento que abraçou. Como diz a música de Gilberto Gil, "toda saudade é a presença da ausência de alguém”. Nós que aqui ficamos, dizemos. Luiz de Sousa Junior, presente!

Campinas, abril de 2021 